This work is licensed under Creative Commons Attribution 4.0 International (CC BY 4.0). [http://creativecommons.org/licenses/by/4.0/]

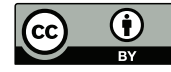

\title{
Radzenie sobie ze stresem oraz zachowania zdrowotne nastolatków w kontekście zachowań agresywnych
}

Joanna Koralewska-Samko | Uniwersytet Gdański https://orcid.org/0000-0002-8386-030X

Katarzyna Sadowska | Uniwersytet Gdański https://orcid.org/0000-0002-1255-0902

Magdalena Spryszyńska | Elbląska Uczelnia Humanistyczno-Ekonomiczna https://orcid.org/0000-0003-1712-3851

Słowa kluczowe: agresja, przemoc adolescencja, zachowania zdrowotne, radzenie sobie

Keywords: aggression, violence, adolescence, health behaviors, coping with

\section{Streszczenie}

Celem badań było zbadanie zależności między zachowaniami zdrowotnymi i strategiami radzenia sobie ze stresem a agresywnością młodzieży gimnazjalnej. W badaniach podjęto próbę zbudowania odpowiedniego modelu, pozwalającego przewidywać poziom agresji uczniów gimnazjów na podstawie wiedzy o ich zachowaniach zdrowotnych i sposobach radzenia sobie ze stresem. W sumie badania objęły grupę 189 uczniów z województwa pomorskiego. Wszystkie badane skale zachowań prozdrowotnych okazały się statystycznie istotnie wpływać na poziom agresji ogólnej. W zakresie sposobów radzenia sobie ze stresem istotny okazał się związek tylko trzech zmiennych z poziomem agresji: aktywnego radzenia sobie ze stresem, wyładowania negatywnych emocji i zażywania substancji psychoaktywnych. Badanie pozwoliło ostatecznie na stworzenie modelu z czterema predyktorami zachowań agresywnych i są to takie czynniki, jak: zachowania profilaktyczne, pozytywne nastawienie psychiczne, wyładowanie oraz zażywanie substancji psychoaktywnych.

\section{Coping with stress and health behaviors of teenagers in the context of aggressive behavior (Summary)}

The aim of the research was to show a correlation between lifestyle choices and stress coping strategies versus the level of aggression among junior high students. The research was to find out whether there are any differences in the level of aggression, stress coping strategies in teenage boys and teenage girls. The research included 189 students from the Pomerania region. The research also aimed at constructing a psychological model that would make it possible to predict levels of aggression based on lifestyle choices and stress coping strategies. All the measured scales of lifestyle choices proved to be statistically relevant when it came to general levels of aggression. The research also showed that factors such as preventative behaviour, positive attitude, unloading the emotions and the use of psychoactive substances are predicators of aggressive behaviour. 


\section{Wstęp}

Pierwotną grupą społeczną, w której rozpoczyna się rozwój i nauka zachowań prozdrowotnych, jest rodzina. To tam następuje pierwotna socjalizacja dziecka, które to następnie wkracza w środowisko rówieśnicze. Od rodziców dziecko uczy się rozumienia takich pojęć, jak zdrowie, dbanie o kondycję czy też zachowanie szkodliwe. W rodzinie dzieci zdobywają wiedzę o tym, jak dbać o stan swojego zdrowia, co należy i w jakiej postaci spożywać, jak należy wypoczywać i jak należy chronić swój organizm, by stwarzać mu dogodne warunki do wzrostu jego sił odpornościowych wobec zagrożeń znajdujących się w otoczeniu. Na postawy dzieci i wzorce ich zachowania mają wpływ również rówieśnicy. Są to wpływy nie zawsze respektujące ustalane przez opiekunów zasady. Dziecko uczy się sposobów omijania zasad, kompromisów i wzorców niepożądanych. Co więcej, często buntuje się przeciwko ustalonym zasadom nawet kosztem własnego zdrowia. Badania pokazują, że dzieci często kształtują zachowania antyzdrowotne, które wpływają na ich zachowania społeczne (Bryła, Kulbacka, Maniecka-Bryła 2011). Przykładem może być tu nadmierne oglądanie telewizji, które to może mieć wpływ na zachowania agresywne u dzieci. Zakres pojęcia agresywności młodzieży oraz jej przejawów jest szeroki i odnosi się zarówno do zaburzeń zachowania, jak i emocji, które w rezultacie prowadzą do łamania norm społeczno-moralno-prawnych. Trudności w respektowaniu norm zachowania zaburzają proces adaptacji dziecka do środowiska i uniemożliwiają właściwe pełnienie ról społecznych. Zaburzenia mogą kształtować się pod wpływem nieprawidłowego rozwoju osobowości lub długotrwałego, wysokiego poziomu doświadczanego stresu spowodowanego niekorzystnymi warunkami życia. W Polsce problem zachowań agresywnych u młodzieży, prowadzących nierzadko do późniejszej przestępczości nieletnich, jest problemem znaczącym. W roku 2007 policja skierowała 109934 dzieci do organizacji i placówek pomocowych ze względu na patologiczną sytuację w rodzinie lub popełnianie przez nieletnich czynów karalnych (większość nacechowana wysokim poziomem agresji i przemocy) (Szymańczak 2009). Rośnie również skala cyberprzemocy i hejtu w multimediach społecznościowych. W samym mieście Gdańsku w roku 2017 nieletni dokonali 1128 czynów karalnych (Biuro Prewencji KGP, Wydział Prewencji 2017). Co ważne, zachowanie dziecka staje się tym bardziej oporne na zmienne im dłużej dziecko będzie je powielać jako uznane przez siebie za normalne i funkcjonalne w warunkach, w których żyje (Opora 2011).

\section{Podstawy teoretyczne}

Definicja zdrowia mówi nam o stanie pełnego fizycznego, umysłowego i społecznego dobrostanu, a nie tylko o braku choroby bądź niepełnosprawności. Daje nam ono możliwość produktywnego życia społecznego i ekonomicznego, jednakże podczas I Krajowej Konferencji Promocji Zdrowia w Polsce padło stwierdzenie „(...) stan zdrowia naszego społeczeństwa jest i ulega stałemu pogorszeniu. Zagraża to dynamicznemu rozwojowi państwa, jest źródłem trudności ekonomicznych, społecznych, obniża też 
wyraźnie jakość życia wielu rodzin i obywateli" (Stanowisko I Krajowej Konferencji Promocji Zdrowia 1991). Istnieje więc potrzeba wszechstronnych działań na rzecz rozpowszechniania i nauki zachowań prozdrowotnych już u najmłodszych, aby kształtować i utrwalać reaktywne, nawykowe lub celowe formy aktywności człowieka, które pozostają w istotnym wzajemnym związku ze zdrowiem. Zachowania zdrowotne obejmują zarówno aktywność prozdrowotną (np. zdrowa dieta), jak i antyzdrowotną (np. palenie papierosów). Preambuła podstawy programowej już w szkole podstawowej zakłada, iż celem kształcenia w szkole jest dbałość o integralny rozwój biologiczny, poznawczy, emocjonalny, społeczny i moralny ucznia, a także kształtowanie postaw prozdrowotnych u dzieci. Ważne jest wdrożenie uczniów od najmłodszych lat do zachowań higienicznych, bezpiecznych dla zdrowia własnego i innych osób, a ponadto utrwalenie wiedzy z zakresu prawidłowego odżywiania się, korzyści płynących z aktywności fizycznej oraz stosowania profilaktyki (Preambuła podstawy programowej do szkół podstawowych 2019/2020). Reaktywne, nawykowe lub celowe formy aktywności człowieka, które pozostają - na gruncie wiedzy obiektywnej o zdrowiu i subiektywnego przekonania - w istotnym wzajemnym związku ze zdrowiem (Sęk 2000). Zachowania zdrowotne obejmują zarówno aktywność prozdrowotną (np. zdrowa dieta, aktywność ruchowa, regularne kontrole lekarskie), jak i antyzdrowotną (np. palenie papierosów, stres, nadmierne obciążenie pracą, brak ruchu).

Z wielu badań wynika, że niewłaściwe zachowania zdrowotne dzieci i młodzieży budzą wiele obaw (mała aktywność ruchowa, sprzęt elektroniczny, używki, nieregularne posiłki, brak dbałości o uzębienie, stany depresyjne itp.). Z badań HBSC (Health Behaviour In School-aged Children 2010) wynika, że odsetek młodzieży szkolnej zgłaszającej problemy ze zdrowiem waha się od 10 do 50\%, a dolegliwości te pogarszają się wraz z wiekiem (Mazur 2010). Pomimo powszechnie uznanej ochronnej roli aktywności fizycznej dla zdrowia odsetek młodych osób spełniających rekomendacje WHO okresowo się zmniejsza. Wyniki ostatniej rundy badań HBSC (2013/14) pokazują, że rekomendacje co do zalecanej intensywnej aktywności fizycznej spełniało tylko 15,8\% ankietowanych nastolatków (Mazur, Małkowska-Szkutnik 2018).

Badania przeprowadzone przez Woynarowską wykazały, że aktywność fizyczna większości uczniów gimnazjum jest niewystarczająca (Woynarowska 2003). Marc Lalond wymienił cztery główne czynniki warunkujące zdrowie: styl życia, środowisko fizyczne, predyspozycje genetyczne, organizacja opieki zdrowotnej oraz jej funkcjonowanie (Wojnarowska 2007). Od czasów „Projektu Reformy Systemu Edukacji” (1998) aż do dziś w propozycji treści programowej (Preambuła podstawy programowej do szkół podstawowych 2019/2020) odnaleźć można konieczność stwarzania dla uczniów warunków do kształtowania pozytywnych nawyków zachowań (Karski 1994). Podczas zmiany ustrojowej w Polsce nastąpiły zmiany w sferze obowiązujących wzorców zachowań, a analiza literatury wskazuje wyraźnie, iż zjawiska patologii społecznej rozwijają się najintensywniej w okresie zmian ustrojowych, kryzysów lub w okresie rozwoju (Hołyst 1989). Okres dorastania (13-16 lat) jest okresem bardzo dynamicznym i wiąże 
się z wieloma zmianami, między innymi w budowie i wyglądzie ciała, psychice, postawach wobec własnej i drugiej płci, pełnieniu ról społecznych, wzroście poziomu hormonów, osiąganiu pełnej kontroli nad emocjami, autonomii w stosunku do rodziców, dokończeniu procesów rozwoju tożsamości, uwewnętrznieniu moralności itp. Potrzeba akceptacji w grupie rówieśniczej może skłaniać nastolatków do wielu zachowań budzących niepokój, takich jak np. zainteresowania substancjami psychoaktywnymi, ryzykowne sporty czy wagary (Rajska-Kulik 1998). Co więcej, potrzeba niezależności zachęca młodzież do buntu przeciwko rodzicom, autorytetom i wartościom, wyrażanego między innymi przez uczestnictwo w subkulturach młodzieżowych, wagary, konflikty z prawem, agresję (Kendall 2012). Szybko rosnąca potrzeba samodzielności widoczna jest w hiperkrytycyzmie młodocianych. Dlatego aktualne badania tego okresu życia są tak ważne zarówno dla rodziców, osób współpracujących z młodzieżą, jak i instytucji pomocowych w celach profilaktyki zachowań młodzieży. Wobec złożoności problematyki adolescencji oraz zmian, jakim ta problematyka podlega w każdym nowym pokoleniu, istnieje potrzeba stałego i szybkiego wykrywania nowych zależności (Żebrowska 1976).

Na szczególną uwagę jako zagrożenie zasługuje agresja nieletnich. Według Siemaszko i in. (2009) od roku 1989 wzrosła liczba przestępstw przeciwko życiu i zdrowiu. Przestępstwa młodocianych (17-21 lat) oraz nieletnich (13-17 lat) są bardziej brutalne i bezwzględne (Ambroziak, Zieliński 2003). W wieku adolescencji agresja może pojawiać się jako reakcja na sytuację trudną. W literaturze podano i opisano różne uwarunkowania agresji wśród młodzieży, na które składają się czynniki indywidualne oraz społeczne, kulturowe i środowiskowe. Według Adama Frączka (1979) agresja to czynność mająca na celu zrobienie krzywdy i spowodowanie utraty cenionych wartości, zadanie bólu fizycznego lub spowodowanie cierpienia moralnego innemu człowiekowi. Różne sytuacje życiowe mają specyficzny wpływ na powstawanie agresji, szczególnie jeśli dodatkowo pobudzać je będą specyficzne okoliczności czy stres. W okresie adolescencji pojawia się wiele sytuacji trudnych. Według Marii Tyszkowej do sytuacji trudnych możemy zaliczyć: sytuacje społecznej ekspozycji, sytuacje nacisku i przymusu, sytuacje społecznego konfliktu. Jak wynika z badań przeprowadzonych przez Tyszkową, dzieci odporne dysponują wyrobionymi wcześniej nawykami reagowania na emocje ujemne korzystnymi z punktu widzenia pokonywania trudności, dzieci nieodporne natomiast kierują się w swym postępowaniu nawykami obronnego reagowania na trudności. Sprawą kluczową jest opanowanie zdolności zachowania kontroli poznawczej nad sytuacją i nad własnymi reakcjami emocjonalnymi (Tyszkowa 1972). Wyniki badań wskazują, że u nieletnich przestępców występuje niedojrzała reakcja na frustrację, a wywołane przeszkodami napięcie emocjonalne niwelowane jest za pomocą zachowań agresywnych. Może to stanowić podstawę do stwierdzenia, że zachodzą istotne związki między sposobami radzenia sobie ze stresem a czynami o charakterze agresywnym. Co więcej, ze względu na rozchwianie emocjonalne występujące w okresie dorastania odporność na stres u nieletnich jest obniżona (Argyle 2001). 


\section{Metodologia badań własnych}

\subsection{Grupa badana}

Badanie przeprowadzono na próbie 189 osób. Uczestnikami badania były dzieci - uczniowie gimnazjów województwa pomorskiego - w wieku od 13 do 17 lat $(M=14,84$ lat; $S D=0,78$ roku). W większości $(58,7 \%)$ były to dziewczynki $(n=111)$. Chłopcy stanowili 41,3\% badanej próby $(n=78)$. Najliczniejszą grupę stanowili uczniowie klas drugich (48\%), nieco mniej było pierwszoklasistów (28\%), a najmniej trzecioklasistów (24\%). Większa część uczestników badania $(58,2 \%)$ pochodziła ze wsi $(n=110)$. Mieszkańcy miasta stanowili $41,8 \%$ próby $(n=79)$. Dobór dzieci do badania poszerzony był o wywiad z rodzicem/prawnym opiekunem dziecka na temat funkcjonowania i struktury rodziny. Dane z wywiadu pomogły w przydziale dzieci do grup. Do badania wybrano dzieci z rodzin pełnych, posiadające jedno lub dwoje rodzeństwa, rodzice posiadali wykształcenie minimum średnie.

\subsection{Narzędzia kwestionariuszowe}

W badaniu wykorzystano następujące narzędzia pomiarowe: Kwestionariusz Agresywności Młodzieży - Reaktywność Emocjonalna (KAM) stworzony przez U. Sajewicz-Radtke, B. Radtke, D. Kalkę, Inwentarz Zachowań Zdrowotnych (IZZ) Z. Juczyńskiego oraz Inwentarz do Pomiaru Radzenia Sobie ze Stresem (Mini-COPE) Ch.S. Carver, w polskiej adaptacji Z. Juczyńskiego i N. Ogińskiej-Bulik.

\section{Kwestionariusz Agresywności Młodzieży - Reaktywność Emocjonalna (KAM)}

Kwestionariusz składa się z 60 pozycji testowych, do których badany ustosunkowuje się na skali pięciostopniowej i przeznaczony jest do diagnozowania poziomu agresji dzieci w wieku 13-16 lat. Narzędzie to zawiera 5 skal pomiarowych: agresja bezpośrednia (użycie siły fizycznej w celu wyrządzenia szkody), agresja pośrednia (zachowania mające wyrządzić krzywdę innej osobie, ale z wyłączeniem przemocy fizycznej, np. plotki, żarty, krzyk, tupanie nogami), drażliwość emocjonalna (tendencja do negatywnych uczuć), opozycyjność (zachowania przeciw autorytetowi, walka z normami i zwyczajami), agresja werbalna (wyrażanie negatywnych emocji). Wynik testu stanowi ogólna suma punktów otrzymanych w poszczególnych skalach.

\section{Inwentarz Zachowań Zdrowotnych (IZZ)}

Kwestionariusz przeznaczony jest do badania osób zarówno zdrowych, jak i chorych. Zawiera 24 stwierdzenia samoopisowe określające różnego rodzaju zachowania związane ze zdrowiem: nawyki żywieniowe (rodzaj i jakość spożywanej żywności), zachowania profilaktyczne (przestrzeganie zaleceń zdrowotnych, uzyskiwanie informacji 
na temat zdrowia i choroby), pozytywne nastawienie psychiczne (unikanie zbyt silnych emocji, stresów i napięć, sytuacji wpływających przygnębiająco, angażowanie się w czynności zastępcze), praktyki zdrowotne (codzienne praktyki dotyczące snu, rekreacji i aktywności fizycznej). Badani proszeni są o zaznaczenie na skali pięciostopniowej, jak często wykonują podane w inwentarzu czynności związane ze zdrowiem.

\section{Inwentarz do Pomiaru Radzenia Sobie ze Stresem (Mini-COPE)}

Kwestionariusz jest narzędziem do badania osób zarówno zdrowych, jak i chorych. Składa się z 28 stwierdzeń wchodzących w skład 14 strategii: aktywne radzenie sobie, planowanie, pozytywne przewartościowanie, poczucie humoru, zwrot ku, poszukiwanie wsparcia emocjonalnego, poszukiwanie wsparcia instrumentalnego, zajmowanie się czymś innym, zaprzeczanie, wyładowanie, zażywanie substancji psychoaktywnych, zaprzestawanie działań, obwinianie siebie. Narzędzie stosuje się do oceny typowych sposobów reagowania i odczuwania w sytuacjach doświadczania silnego stresu. Zadaniem badanego jest ustosunkować się do twierdzeń na czterostopniowej skali, gdzie 0 oznacza „prawie nigdy tak nie postępuje”, a 3 „prawie zawsze tak postępuje”. Wynik stanowi ogólna punktacja liczona oddzielnie w każdej ze skal.

\section{Wyniki badań własnych}

\subsection{Cel badań własnych}

Celem przeprowadzonych badań było podjęcie próby stworzenia modelu, który wyjaśniałby zachowania agresywne u młodzieży gimnazjalnej na podstawie prezentowanych przez nich zachowań prozdrowotnych oraz strategii radzenia sobie ze stresem. Postawiono pytania badawcze:

1. Czy istnieje korelacja pomiędzy zachowaniami prozdrowotnymi a poziomem agresji u młodzieży?

2. Czy istnieje korelacja pomiędzy strategiami radzenia sobie ze stresem a poziomem agresji u młodzieży?

Zmiennymi niezależnymi w badaniu były zachowania prozdrowotne (prawidłowe nawyki żywieniowe, zachowania profilaktyczne, pozytywne nastawienie oraz praktyki zdrowotne) oraz strategie radzenia sobie ze stresem (aktywne radzenie sobie, planowanie, akceptacja, poczucie humoru, zwrot ku religii, poszukiwanie wsparcia emocjonalnego oraz instrumentalnego, zajmowanie się czymś innym, zaprzeczanie, wyładowanie, zażywanie substancji psychoaktywnych). Zmienną zależną była natomiast agresja ogólna rozumiana przez autorów narzędzia pomiarowego jako względnie stała predyspozycja, gotowość jednostki do zachowań agresywnych. Autorzy definiują agresywność jako intencjonalne działanie nakierowane (bezpośrednio lub pośrednio) na wyrządzenie krzywdy innej osobie, której dążeniem jest uniknięcie tego 
działania. Badacze za zachowanie agresywne uznają także wszelkie przejawy ekspresji uczuć agresywnych.

\subsection{Procedura badania}

Procedurę badania rozpoczęto od uzyskania zgody dyrektorów wybranych placówek edukacyjnych na przeprowadzenie badań na terenie instytucji. Następnie badacze uzyskali zgody rodziców/opiekunów prawnych dzieci na przeprowadzenie badania. Rodzice zostali powiadomieni o celu badania oraz sposobie wykorzystania wyników analiz. Wywiady z rodzicami na temat struktury i funkcjonowania rodziny pomogły w doborze dzieci do grup. Uczniowie wypełniali kwestionariusze indywidualnie w wersji elektronicznej w zaadaptowanych specjalnie do badania salach na terenie szkół. Czas badania wynosił około 45 minut.

\section{Wyniki}

W badaniu zastosowano analizy statystyczne przy użyciu pakietu IBM SPSS Statistics. Za jego pomocą przeprowadzono dwuczynnikową analizę wariancji oraz analizę regresji liniowej. Za poziom istotności uznano $p<0,05$. Pierwszym etapem analizy statystycznej było przeprowadzenie testów normalności rozkładu zmiennych ilościowych mierzonych w badaniu. Wynik serii testów Kołmogorowa-Smirnowa, a także miar asymetrii rozkładu zmiennych pozwala twierdzić, że wszystkie zmienne ilościowe mierzone testami KAM i IZZ mają rozkłady zbliżone do rozkładu normalnego.

\subsection{Model predykcyjny poziomu agresji u uczniów gimnazjów}

W badaniach podjęto próbę zbudowania odpowiedniego modelu, pozwalającego przewidywać poziom agresji uczniów gimnazjów na podstawie wiedzy o podejmowanych przez nich zachowaniach zdrowotnych i sposobach radzenia sobie ze stresem. Aby przeprowadzić taką analizę, najpierw sprawdzono korelacje między potencjalnymi predyktorami a zmienną objaśnianą, tak aby do modelu włączone zostały tylko predyktory istotnie związane z poziomem agresji. Jednym z powodów, dla których zdecydowano się na taką wstępną analizę, była bardzo duża liczba predyktorów, które potencjalnie miały być włączone do modelu. Skorelowanie skal zachowań zdrowotnych z poziomem agresji ogólnej sprawdzano za pomocą testu $r$ Pearsona. Związek skal radzenia sobie ze stresem z ogólnym poziomem agresji testowano natomiast testem rho Spearmana - nieparametrycznym odpowiednikiem testu $r$. Przeprowadzone testy pozwoliły ustalić, że wszystkie podskale testu IZZ korelują istotnie, ujemnie z poziomem agresji. W zakresie sposobów radzenia sobie ze stresem istotny okazał się związek tylko trzech zmiennych z poziomem agresji: aktywnego radzenia sobie, wyładowania i zażywania substancji psychoaktywnych. Przy czym pierwsza z wymienionych skal korelowała ujemnie z poziomem agresji, a pozostałe dwie dodatnio. 
Tabela 1. Związek nawyków zdrowotnych i sposobów radzenia sobie ze stresem z poziomem agresji ogólnej

\begin{tabular}{|c|c|c|}
\hline & & Agresja ogólna \\
\hline \multirow{4}{*}{$\begin{array}{l}\text { Korelacje } \\
r \text { Pearsona }\end{array}$} & Prawidłowe nawyki żywieniowe & $-0,184^{*}$ \\
\hline & Zachowania profilaktyczne & $-0,239^{*}$ \\
\hline & Pozytywne nastawienie psychiczne & $-0,353^{*}$ \\
\hline & Praktyki zdrowotne & $-0,151^{*}$ \\
\hline \multirow{11}{*}{$\begin{array}{l}\text { Korelacje } \\
\text { rho Spearmana }\end{array}$} & Aktywne radzenie sobie & $-0,172^{*}$ \\
\hline & Planowanie & $-0,096$ \\
\hline & Akceptacja & $-0,032$ \\
\hline & Poczucie humoru & $-0,110$ \\
\hline & Zwrot ku religii & 0,077 \\
\hline & Poszukiwanie wsparcia emocjonalnego & $-0,027$ \\
\hline & Poszukiwanie wsparcia instrumentalnego & 0,082 \\
\hline & Zajmowanie się czymś innym & 0,010 \\
\hline & Zaprzeczanie & $-0,010$ \\
\hline & Wyładowanie & $0,181^{*}$ \\
\hline & Zażywanie substancji psychoaktywnych & $0,294^{*}$ \\
\hline
\end{tabular}

Uwaga: * istotność na poziomie $\mathrm{p}<0,05$.

Źródło: Opracowanie własne.

Następnie przystąpiono do przeprowadzenia analizy regresji liniowej. Do modelu predykcyjnego włączono te zmienne, które okazały się istotnie skorelowane z poziomem zmiennej zależnej. Zastosowana została metoda krokowa eliminacji wstecznej dla wprowadzania predyktorów do modelu. Ostateczny model składał się z czterech predyktorów. Były to: zachowania profilaktyczne, pozytywne nastawienie psychiczne, wyładowanie oraz zażywanie substancji psychoaktywnych. Model ten wyjaśniał $25 \%$ wariancji zmiennej zależnej i był dobrze dopasowany do danych, $F(4,181)=14,89$; $p<0,05$. Zachowania profilaktyczne i pozytywne nastawienie psychiczne okazały się ujemnie związane z poziomem agresji ogólnej, natomiast wyładowanie i zażywanie substancji psychoaktywnych związane były ze zmienną zależną dodatnio. Silniejszymi predyktorami były zażywanie substancji psychoaktywnych (Beta $=0,28$ ) oraz pozytywne nastawienie psychiczne (Beta $=-0,27$ ). Wyniki te świadczyć mogą więc o tym, iż zażywanie środków psychoaktywnych oraz taki sposób radzenia sobie ze stresem jak wyładowanie może występować w powiązaniu z wyższą agresją, natomiast angażowanie się w zachowania profilaktyczne oraz pozytywne nastawienie - z niższą agresją ogólną. 
Tabela 2. Współczynniki regresji liniowej w modelu predykcyjnym poziomu agresji ogólnej

\begin{tabular}{|c|c|c|c|c|c|c|}
\hline & $B$ & SE & Beta & $R^{2}$ & $\Delta R^{2}$ & $\begin{array}{l}\text { Istotność } \\
\text { Fzmiany }\end{array}$ \\
\hline Model 1 & & & & 0,25 & $<0,01$ & \\
\hline (Stała) & 173,16 & 12,96 & & & & \\
\hline Prawidłowe nawyki żywieniowe & $-0,32$ & 0,52 & $-0,05$ & & & \\
\hline Zachowania profilaktyczne & $-0,74$ & 0,51 & $-0,11$ & & & \\
\hline Pozytywne nastawienie psychiczne & $-1,74$ & 0,59 & $-0,25^{*}$ & & & \\
\hline Praktyki zdrowotne & 0,12 & 0,59 & 0,02 & & & \\
\hline Aktywne radzenie sobie & $-2,83$ & 3,38 & $-0,06$ & & & \\
\hline Wyładowanie & 4,84 & 2,75 & $0,12^{\wedge}$ & & & \\
\hline Zażywanie substancji psychoaktywnych & 12,36 & 2,94 & $0,30^{*}$ & & & \\
\hline Model 2 & & & & 0,25 & $<0,01$ & 0,845 \\
\hline (Stała) & 174,07 & 12,06 & & & & \\
\hline Prawidłowe nawyki żywieniowe & $-0,30$ & 0,51 & $-0,04$ & & & \\
\hline Zachowania profilaktyczne & $-0,74$ & 0,51 & $-0,11$ & & & \\
\hline Pozytywne nastawienie psychiczne & $-1,69$ & 0,54 & $-0,24^{*}$ & & & \\
\hline Aktywne radzenie sobie & $-2,88$ & 3,36 & $-0,06$ & & & \\
\hline Wyładowanie & 4,77 & 2,73 & $0,12^{\wedge}$ & & & \\
\hline Zażywanie substancji psychoaktywnych & 12,44 & 2,91 & $0,30 *$ & & & \\
\hline Model 3 & & & & 0,25 & $<0,01$ & 0,558 \\
\hline (Stała) & 171,70 & 11,34 & & & & \\
\hline Zachowania profilaktyczne & $-0,85$ & 0,47 & $-0,13^{\wedge}$ & & & \\
\hline Pozytywne nastawienie psychiczne & $-1,74$ & 0,53 & $-0,25^{*}$ & & & \\
\hline Aktywne radzenie sobie & $-2,92$ & 3,35 & $-0,06$ & & & \\
\hline Wyładowanie & 4,76 & 2,72 & $0,12^{\wedge}$ & & & \\
\hline Zażywanie substancji psychoaktywnych & 12,46 & 2,90 & $0,30^{*}$ & & & \\
\hline Model 4 & & & & 0,25 & $<0,01$ & 0,384 \\
\hline (Stała) & 170,66 & 11,27 & & & & \\
\hline Zachowania profilaktyczne & $-0,89$ & 0,47 & $-0,14 \wedge$ & & & \\
\hline Pozytywne nastawienie psychiczne & $-1,89$ & 0,50 & $-0,27^{*}$ & & & \\
\hline Wyładowanie & 4,94 & 2,71 & $0,12^{\wedge}$ & & & \\
\hline Zażywanie substancji psychoaktywnych & 11,70 & 2,77 & $0,28^{*}$ & & & \\
\hline
\end{tabular}

Uwaga: * istotność na poziomie $\mathrm{p}<0,05 ; \wedge$ istotność na poziomie $\mathrm{p}<0,09$.

Źródło: Opracowanie własne.

Równanie regresji można zapisać $\mathrm{w}$ postaci następującego wzoru: poziom agresji = $170+4,94 \times$ Wyładowanie $+11,70 \times$ Zażywanie substancji psych. $-0,89 \times$ Zachowania profilaktyczne $-1,89 \times$ Pozytywne nastawienie psychiczne. 


\section{Zakończenie}

Badania pozwoliły odpowiedzieć na postawione pytania badawcze dotyczące związku między zachowaniami prozdrowotnymi oraz strategiami radzenia sobie ze stresem i agresywnością. Wyniki pokazały, że zachowania prozdrowotne, takie jak np. prawidłowe nawyki żywieniowe oraz właściwe strategie radzenia sobie ze stresem, np. poczucie humoru, minimalizują poziom agresji u młodzieży. Wniosek ten daje ogromne możliwości wszelkim instytucjom pomocowym oraz programom profilaktycznym. Z analiz wynika, że dzieci, które stosują takie strategie radzenia sobie ze stresem, jak wyładowania czy sięganie po środki psychoaktywne, reagują częściej w sposób agresywny, natomiast dzieci potrafiące korzystać z aktywnych sposobów radzenia sobie ze stresem prezentują znacznie mniej zachowań agresywnych. Biorąc to pod uwagę, należałoby rozważyć kwestię pracy profilaktycznej z młodzieżą w taki sposób, aby nauczyć ich sięgania właśnie po aktywne sposoby radzenia sobie. Podobne wnioski płyną odnośnie do zachowań prozdrowotnych. Badania pokazują, że dzieci o pozytywnym nastawieniu oraz częściej stosujące zachowania profilaktyczne prezentują mniej zachowań agresywnych. W tym kontekście bardzo ważne jest uświadomienie zarówno rodzicom, jak i nauczycielom wagi kształtowania u dzieci właściwych postaw i zachowań prozdrowotnych (profilaktyka zachowań). Wykształcenie u dzieci nawyku i potrzeby stosowania się do zaleceń zdrowotnych, przestrzegania prawidłowego rytmu snu, rekreacji oraz angażowania się w aktywność fizyczną może przyczyniać się do obniżenia poziomu agresji u młodzieży. Bardzo ważne jest nauczenie dzieci właściwych metod rozładowania napięcia (Daniluk i in. 2013). Wiek adolescencji jest wiekiem trudnym, pełnym wyzwań, konfliktów i problemów. W tym wieku młodzież często eksperymentuje, angażując się w zachowania ryzykowne. Według danych epidemiologicznych z 2019 roku Krajowego Biura ds. Przeciwdziałania Narkomani (Grabowska, Gwiazda 2019) w roku 2018 napoje alkoholowe okazały się najbardziej rozpowszechnioną substancją psychoaktywną wśród młodzieży szkolnej, po którą sięgano częściej niż po papierosy czy narkotyki. Jednakże pomimo tak dużej w ówczesnym świecie dostępności różnego rodzaju używek i środków psychoaktywnych odsetek młodzieży sięgającej po papierosy maleje z 22\% w roku 2008 do 18\% w 2019. Ponadto w 2016 roku o „dopalaczach” słyszało 68\% ankietowanych, a w 2018 roku - 64\%. Dane te sugerować mogą pozytywne działanie licznych programów i akcji profilaktycznych zarówno w szkołach, jak i tych prowadzonych przez organizacje pozarządowe. Dana wiedza oraz wyniki badań dotyczących predyktorów zachowań agresywnych powinna posłużyć do rozbudowy i ewaluacji celów profilaktycznych w ramach projektów, programów wychowawczych i edukacyjnych. Poszerzenie edukacji prozdrowotnej zawierającej elementy skutecznego rozwiązywania problemów radzenia sobie ze stresem może mieć duży wpływ na rozwój i późniejsze funkcjonowanie dorastającej młodzieży. 


\section{Bibliografia}

Ambroziak W., Zieliński F. 2003, Młodociani mordercy. Studia nad agresją i zbrodniq, Poznań.

Argyle M., 2001, Psychologia stosunków międzyludzkich, Warszawa.

Babska Z., Łapińska R., Przetacznikowa M., Spionek H., Włodarski Z., Wołoszynow L., Żebrowska M., 1976 [w:] M. Żebrowska (red.), Psychologia rozwojowa dzieci i młodzieży, Warszawa.

Biuro Prewencji KGP, Informacja dotycząca stanu zagrożenia przestępczością nieletnich w Polsce w 2018 roku.

Bryła M., Kulbacka E., Maniecka-Bryła I., 2011, Rola telewizji w kształtowaniu zachowań zdrowotnych dzieci i młodzieży. Cz. III. Zachowania antyzdrowotne , "Hygeia Public Health”, Vol. 46, No. 2.

Bykowska B., Szulc M. (red.), 2006, Zagrożenia współczesnej młodzieży polskiej - w poszukiwaniu tożsamości..., Gdańsk.

Daniluk A., Kopeć A., Rajecka P., Stępień-Słodkowska M., 2013, Czynniki warunkujące zachowania agresywne wśród młodzieży, ,JJournal of Health Sciences", Vol. 13, No. 3.

Frączek A. (red.), 1979, Studia nad psychologicznymi mechanizmami czynności agresywnych, Wrocław-Warszawa-Gdańsk.

Grabowska M., Gwiazda M., 2019, Młodzież 2018, Warszawa.

Hołyst B., 1989, Kryminologia, Warszawa.

Karski J.B., 1994, Promocja zdrowia we współczesnych systemach ochrony zdrowia, Problemy współpracy na rzecz zdrowia. Materiały z konferencji, 23-24 września 1994, Warszawa.

Kendall P.C., 2012, Zaburzenia okresu dzieciństwa i adolescencji. Techniki terapeutyczne dla profesjonalistów i rodziców, Gdańsk.

Kozaczuk F., 2005, Świat wartości młodzieży z symptomami niedostosowania społecznego. Analiza porównawcza postaw wobec norm i wartości nieletnich oraz młodzieży szkolnej i skazanych, Rzeszów. Mazur J., 2010, Zdrowie i zachowania zdrowotne młodzieży szkolnej na podstawie badań HBSC 2010, Warszawa.

Mazur J., Małkowska-Szkutnik A. (red.), 2018, Zdrowie uczniów w 2018 roku na tle nowego modelu badań HBSC, Warszawa.

Nowak A., 2000, Wybrane zjawiska powodujące zagrożenia społeczne (rozpoznawanie i przeciwdziałanie), Kraków.

Opora R., 2011, Nieletni niedostosowani społecznie, lecz odporni psychicznie [w:] W. Junik (red.), Teoria-badania-praktyka. Resilience, Warszawa.

Rajska-Kulik I., 1998, Osobowościowe i sytuacyjne tło motywacyjne czynów agresywnych, w tym zabójstw dokonanych przez nieletnich (w świetle psychologicznego opiniodawstwa sądowego) [w:] J. Papież, A. Płukis (red.), Przemoc dzieci i młodzieży, Toruń.

Reykowski J., 1977, ,Spontaniczna agresja i spontaniczne czynniki ją hamujące. „Przegląd Psychologiczny", t. 20, nr 2.

Sęk H, 2000, Zdrowie behawioralne [w:] J. Strelau (red.), Psychologia. Podręcznik akademicki t. 3, Gdańsk. Siemaszko A., Gruszczyńska B. i in., 2009, Atlas przestępczości w Polsce 4, Warszawa.

Sierosławski J., 2003, Używanie alkoholu i narkotyków przez młodzież szkolnq, Raport z ogólnopolskich badań ankietowych zrealizowanych w 2003 roku. Europejski program badań w szkołach ESPAD, Warszawa.

Stanowisko I Krajowej Konferencji Promocji Zdrowia, 13 października 1991 r. 
Szymańczak J., 2009, Zachowania problemowe dzieci i młodzieży [w:] J. Szymańczak, Dzieci z grupy ryzyka, ",Studia BAS", nr 1(17).

Tyszkowa M., 1972, Problemy psychicznej odporności dzieci i młodzieży, Warszawa.

Tyszkowa M., 1978, Sytuacyjno-poznawcza koncepcja odporności psychicznej, „Przegląd Psychologiczny", t. 21, nr 1.

Wojtczak A., 2009, Zdrowie publiczne, wyzwanie dla systemów zdrowia XXI wieku, Warszawa.

Woynarowska B., 2003, Rozwijanie umiejętności życiowych w edukacji zdrowotnej,,,Wychowanie Fizyczne i Zdrowotne" 2003, nr 1.

Woynarowska B., 2007, Edukacja zdrowotna, Warszawa.

\section{Biogramy}

Joanna Koralewska-Samko - absolwentka psychologii na Uniwersytecie Gdańskim; swoją edukację poszerzyła o studia Psychologii Klinicznej na Uniwersytecie Medycznym w Gdańsku. Ukończyła również kurs mediatora sądowego. W 2018 r. obroniła tytuł doktora psychologii na Uniwersytecie Gdańskim. Obecnie jest w trakcie 4-letniego kursu psychoterapii systemowej w Krakowskim Ośrodku Szkoleń Systemowych. Pracuje jako wykładowca akademicki na Uniwersytecie Gdańskim, a także jako terapeuta z młodzieżą, dorosłymi oraz rodzinami, prowadząc prywatną praktykę psychologiczną. Pracuje również jako psycholog w jednym z gdańskich liceów.

Katarzyna Sadlowska - absolwentka psychologii na Uniwersytecie Gdańskim; swoją edukację poszerzyła między innymi o wiedzę z oligofrenopedagogiki oraz liczne kursy i szkolenia z oferty pomocy psychologicznej dziecku i rodzinie. Obecnie jest w trakcie 4-letniego kursu psychoterapii systemowej w Krakowskim Ośrodku Szkoleń Systemowych. W 2018 r. obroniła tytuł doktora psychologii na Uniwersytecie Gdańskim; praca dyplomowa dotyczyła dzieci chorujących na mukowiscydozę. Pracuje z dziećmi i młodzieżą w szkole podstawowej oraz współpracuje z MOPR, udzielając wsparcia psychologicznego beneficjentom.

Magdalena Spryszyńska - psycholog, doktor nauk społecznych z zakresu psychologii. Studia doktoranckie ukończyła na Uniwersytecie Gdańskim, zaś magisterskie studia psychologiczne w Szkole Wyższej Psychologii Społecznej w Warszawie. Dodatkowo ukończyła wiele kursów i szkoleń specjalistycznych, w tym m.in.: terapia małżeństw i par w podejściu systemowym, terapia lęku i nieśmiałości, pomoc terapeutyczna dla osób doświadczających przemocy. Prowadzi prywatną praktykę psychologiczną, udzielając poradnictwa i wsparcia psychologicznego osobom potrzebującym oraz przeprowadzając warsztaty i szkolenia dla różnych instytucji. Pracuje także jako psycholog szkolny i wykładowca na studiach podyplomowych w Elbląskiej Uczelni Humanistyczno-Ekonomicznej. 